\title{
СУТНІСНІ ХАРАКТЕРИСТИКИ ТА СТРУКТУРНІ КОМПОНЕНТИ ЕМОЦІЙНОЇ ЗРІЛОСТІ ПРАЦІВНИКІВ КОМЕРЦІЙНИХ БАНКІВ
}

УДК: 159.942:159.923

\section{Ващенко Ірина Володимирівна}

Доктор психологічних наук, професор, професор кафедри загальної психології, Київський начіональний університет імені Тараса Шевченка, м. Київ (Украӥна)

\section{Онуфрієеа Ліана Анатолӥвна}

Кандидат психологічних наук, доиент, професор кафедри, завідувач кафедри загальної та практичної психології, Кам'янець-Подільський національний університет імені Івана Огієнка, м. Кам'янець-

Подільський (Украӥна)

\begin{abstract}
Анотація. $\quad$ у статті представлено огляд $i$ аналіз проблеми емоційної зрілості особистості. Обгрунтовано розуміння емоційної зрілості у працях видатних психологів сучасності. Показано, щуо розвиток емоційної зрілості важливий для працівників сочіономічних професій, до яких відносяться й банківські працівники. Доведено, щзо психологічні особливості емоційної зрілості у працівників комерційних банків наступні: в емоційно зрілих - висока і середня емоційна стабільність; низькі, оптимальні характеристики негативної емоційності; високий рівень позитивної емоційності; високий рівень емоиійної самосвідомості; в емоційно незрілих низька емоційна стабільність; високий рівень негативної емоційності; низький рівень позитивної емоиійності та сформованості емоичійної самосвідомості. Показано, щчо критеріями емоційної зрілості особистості $\epsilon$ : чутливість, відкритість емоційному досвіду; усвідомленість; адекватність прояву $і$ вираження почуттів (відповідність зовнішній ситуації, внутрішньому стану); психологічне благополуччя (впевненість в собі, задоволеність життям, відсутність психосоматичних симптомів); зрілі способи перетворення емочій (сублімаџія, гумор, творчість); довільність (вміння управляти власними емочійними переживаннями і власною поведінкою).
\end{abstract}

Ключові слова: емоиійна зрілість, працчівник комериійного банку, емоційна стабільність, емоиійна самосвідомість.

Вступ. Соціальні, політичні, економіч- ства зумовлюють переоцінку і становлення ні, моральні зміни у сучасному житті суспіль- 
Змінюється динаміка всіх процесів, до яких включена особистість, що вимагає від неї активної та ефективної адаптації до нових умов. Однак, для соціальної успішності особистості необхідні не тільки академічні знання, професійна вмілість, але й соціальні вміння і навички, зокрема здатність розуміти свої і чужі емоційні реакції, вміння керувати своїми емоціями, адекватне реагування в емоційно насичених ситуаціях. Тому стає очевидною необхідність формування емоційної зрілості особистості на різних етапах соціалізації та професійного становлення. Недослідженість питань щодо сутнісних характеристик і структурних компонентів емоційної зрілості фахівців банківської сфери спонукала нас до з'ясування цього аспекту окресленої проблеми.

Аналіз останніх досліджень і публікацій. У ході наукового пошукування з'ясовано, що осмислення емоційної зрілості здійснювалося через вивчення iï сутності [3; 5-6 та ін.], близькі за значенням поняття «емоційний інтелект» [4 та ін.], «емоційна компетентність» (К. Молоней та ін.), «емоційна гнучкість» (О. Яковлєва та ін.), «емоційна саморегуляція» (I. Волженцева, Н. Завацька, О. Конопкін та ін.), «емоційна розумність» (Н. Коврига, Е. Носенко та ін.), «емоційне самоусвідомлення» [2 та ін.].

У зв'язку з тим, що зміст емоційної зрілості неможливо розглядати без аналізу дефініцій, що визначають якісні його характеристики, осмислимо найчастіше вживані визна- чення. Так, за Н. Антоновою емоційна зрілість - це «сукупність психологічних властивостей, що характеризують людину як здатну відчувати і здатну контролювати емоції, тобто здатну до адекватної спонтанності та свідомої саморегуляції емоційних проявів («я маю право відчувати; я знаю які емоції можу відчувати і що їх викликає; я вмію управляти своїми емоціями») [1, с. 12].

\section{О. Кочарян та М. Півень поняття} «емоційна зрілість» визначають як певний рівень розвитку особистості дорослої людини, яка характеризується відкритістю емоційному досвіду, усвідомленням власних почуттів та прийняттям їх, розвиненою емоційною сферою і емоційною саморегуляцією, здатністю адекватно ситуації і згідно з власними переживаннями проявляти і виражати емоції і почуття [4, с. 142$]$.

3 погляду О. Чудіної «емоційно зріла особистість - це особистість дорослої людини, відкрита емоційному досвіду, яка усвідомлює власні почуття і приймає за них відповідальність, яка володіє розвиненою емоційною сферою й емоційною стійкістю, здатна адекватно ситуації виявляти і виражати емоції і почуття, здатна гнучко і творчо жити з власними емоційними переживаннями» [6, с. 115].

Досліджуючи емоційну зрілість особистості, науковці [3; 5-7 та ін.] прагнули виділити іï характерні ознаки: усвідомленість (розуміння) власних і чужих емоційних станів, почуттів, переживань та адекватність їх вира- 
ження; відповідальність за свої емоційні стани, почуття, переживання; довільність, вміння контролювати, керувати своїми емоціями i переживаннями; емоційне реагування, адекватне віковим, соціокультурним нормам, потребам, цінностям і інтересам суб'єкта; позитивне ставлення до світу, до «Іншого», до себе, свого життя, свого майбутнього; емоційна стійкість як стійке переважання позитивних емоцій; здатність отримувати та надавати емоційну підтримку, самопідтримку, «опора на себе»; здатність до близькості, любові; розвинута емпатія та ін.

Заслуговують на увагу дослідження, присвячені визначенню критеріїв емоційної зрілості особистості [4, с. 143]: здатність розуміти, усвідомлювати власні емоції та емоції інших людей; здатність вербалізувати їх; здатність адекватно проявляти і виражати емоції, i почуття в різних соціальних ситуаціях, враховуючи і суспільні норми вираження емоцій, $\mathrm{i}$ реальність самої ситуації, і власний емоційний стан; здатність приймати власні емоції і нести за них відповідальність; здатність до емпатії; здатність природно, спонтанно виражати пережиті емоції в міміці, жестах, інтонації та ін.

Опис критеріїв емоційної зрілості особистості також здійснює М. Кандиба, до яких відносить: чутливість, відкритість емоційному досвіду; усвідомленість; адекватність прояву і вираження почуттів (відповідність зовнішній ситуації, внутрішньому стану); психологічне благополуччя (впевненість в собі, задоволе- ність життям, відсутність психосоматичних симптомів); зрілі способи перетворення емоцій (сублімація, гумор, творчість); довільність (вміння управляти власними емоційними переживаннями i власною поведінкою) [3, c. 123].

Отже, емоційну зрілість розуміють як певний рівень розвитку особистості дорослої людини, який характеризується відкритістю емоційному досвіду, усвідомленням власних почуттів і прийняттям їх, розвиненою емоційною сферою і емоційною саморегуляцією, здатністю адекватно ситуації і згідно з власними переживаннями проявляти і виражати емоції і почуття.

Мета статті: визначити та розкрити сутнісні характеристики і структурні компоненти емоційної зрілості працівників комерційних банків.

\section{Завдання статті}

1.Розкрити характерні психологічні особливості емоційно зрілих і незрілих працівників банків.

2.Визначити сутнісні характеристики i структурні компоненти емоційної зрілості працівників комерційних банків

3.Визначити і проаналізувати показники емоційної незрілості працівників комерційних банків.

Методи дослідження. Для вирішення поставленої мети були використані методики: «Шкала емоційної зрілості» (М. Аткінсон); «Характеристики емоційності» (Є. Ільїн); 
«Емоційна стабільність» «Методика діагностики

(Б. Смірнов); емоційносTi» (В. Русалов, модиф.

А. Грецова); «Емоційна самосвідомість» (О. Власова). Вибірку склали 60 осіб, які працюють у комерційних банках м. Кам'янець-Подільський (ПАО «Райффайзен банк Аваль», ПАО «Укрексімбанк», ПАО «Кредобанк», ПАО «Альфа-банк»). Емпіричним дослідженням було охоплено 60 осіб: 20 керівників відділень банків, 20 фінансових консультантів, 20 касирів.

Результати дослідження. Аналіз отриманих даних показав, що загалом високий рівень емоційної зрілості був у 33,3 \% досліджуваних. Тобто третина всіх досліджуваних здатна як до розуміння емоцій, так і до їх висловлення, володіє навичками емоційної саморегуляції, толерантна у ставленні до інших, готова до співчуття й емоційної підтримки. Простежити прояви емоційної зрілості у них можна через вміння вирішувати загострені ситуації із збереженням доброзичливих відносин із клієнтами, колегами тощо; здатність аналізувати емоційний стан іншої людини, i, відповідно, використовувати конструктивні техніки спілкування з нею; вміння адаптувати власні висловлювання і рефлексувати емоції, а також їх емпатійність.

Середній рівень емоційної зрілості виявлено у 38,3 \% всіх досліджуваних. Тобто досліджувані здатні до емоційної саморегуляції емоцій, усвідомлення і вербалізації влас- них емоцій і емоцій інших. Однак, їм бракує вміння адекватно підбирати спосіб реагування на життєві події, конструктивно вирішувати виникаючі проблеми і долати виникаючі під час взаємодії з колегами, клієнтами, керівниц-

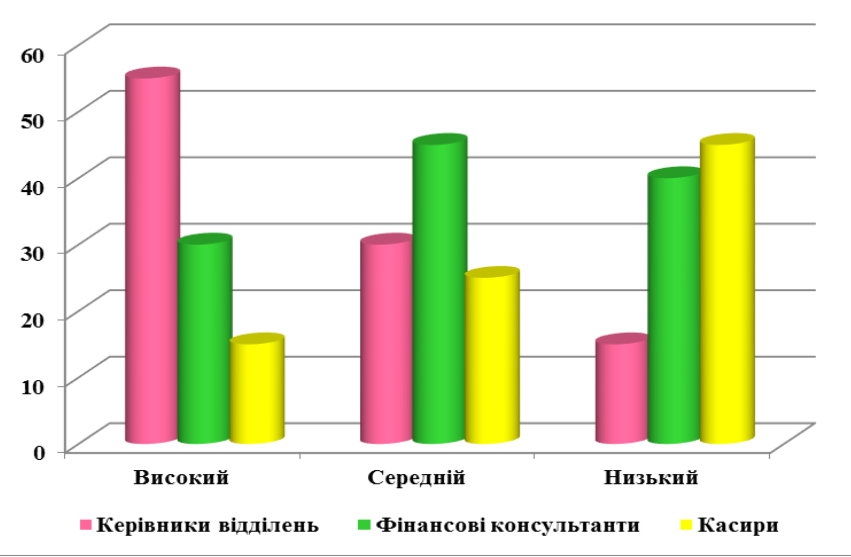

Рис.1. Рівні емоційної зрілості досліджуваних

твом чи підлеглими бар'єри спілкування.

Низький рівень емоційної зрілості виявлено у 28,4 \% осіб. Вони відрізняються агресивністю, імпульсивністю, не володіють усвідомленим ставленням до власної емоційної сфери, нездатні до регуляції емоцій. У них наявні як прояви тривожності, депресивності, так і роздратованості, негативізму. Низька самооцінка, невпевненість у собі і своїх силах, мотивація уникнення невдач у виконуваній діяльності.

Подальший аналіз даних свідчить про те, що високий рівень емоційної зрілості був у 55 \% керівників відділень, у 30 \% фінансових консультантів і у $15 \%$ касирів. Середній рівень емоційної зрілості виявлено у 30 \% кері- 
вників відділень, у 45 \% фінансових консультантів і $40 \%$ касирів. Низький рівень емоційної зрілості виявлено у $45 \%$ касирів, у $25 \%$ фінансових консультантів і $15 \%$ керівників відділень. Отже, касирам бракує вмінь 3 діагностики психоемоційного стану, недосконалість їх емоційної компетентності відбивається на якісному обслуговуванні клієнтів, що, в свою чергу, несприятливо впливає на імідж комерційного банку.

Аналіз показників негативної емоційності досліджуваних свідчить про наявність у досліджуваних переважно середнього (40\% осіб) і високого (36,7\% осіб) рівнів, що не $\epsilon$ оптимальним як для їх професійної діяльності, так і для їх особистісного розвитку. Надмірні емоційні реакції на різні події оточуючого життя, репліки клієнтів перешкоджають успішному виконанню професійних обов'язків, дотриманню правил корпоративної етики та обслуговуванню клієнтів.

Показники інтенсивності емоцій переважно відповідали середньому (46,7 \% осіб) i високому (30\% осіб) рівням. Тобто висока інтенсивність емоцій змушує людину надмірно переживати емоції, і, як результат, людина стає більш імпульсивною, дратівливою, експресивно виражає свої емоції, їй важко здійснювати аналіз і контроль емоцій, навички саморегуляції є недосконалими.

Щодо показника тривалість емоцій, то у 33,3 \% досліджуваних він посів високий рівень. Тобто досліджувані схильні досить три- валий час переживати емоції, їм важко переключатися на інші види діяльності, забувати минулі події. Їх надмірне занурення у власний світ переживань, свідчать про схильність до надмірного самокопання й самозвинувачення тощо.

Серед досліджуваних спостерігається високий і середній рівні негативного впливу емоцій на ефективність діяльності та спілкування (у 36,7 \% та 40 \%). Тільки 23,3 \% досліджуваних здатні до адекватного реагування на різні події і до здійснення подальшої професійної діяльності, не допускають впливу емоційної сфери на продуктивність професійної діяльності та якість спілкування 3 клієнтами і колегами. Отже, високий рівень негативного впливу емоцій на ефективність професійної і комунікативної діяльності не є оптимальним показником для банківських працівників, оскільки перешкоджає успішному обслуговуванню клієнтів, призводить до виникнення професійного стресу.

Загалом тільки 23,3-25\% осіб мають низькі, оптимальні показники емоційності, тобто є зрілими і стійкими, здатними до регулювання впливу емоцій на психофізичний стан та якість виконуваної діяльності, схильні до усвідомлення і рефлексії емоцій, не зациклені на негативних переживаннях.

Відповідно до узагальненого показника негативної емоційності - 23,3 \% осіб є емоційно зрілими, у 40 \% досліджуваних - середній рівень, а в $36,7 \%$ осіб - високий рівень, що 
вказує на їх високу емоційну збудливість, інтенсивне переживання негативу, значну тривалість емоційних реакцій на події життя i професійну діяльність. При цьому у керівників відділень банків, фінансових консультантів і касирів спостерігаються різні рівні емоційної збудливості. Так, високий, неоптимальний рівень емоційної збудливості, виявлено у $25 \%$ керівників, $35 \%$ консультантів і $50 \%$ касирів. Оптимальним показником низької збудливості володіють лише 45 \% керівників і незначна частина тих, хто обіймає інші посади.

Щодо інтенсивності емоцій - високий iii рівень виявлено у $20 \%$ керівників, $30 \%$ консультантів і $40 \%$ касирів. Високу тривалість емоцій, їх надмірне переживання і нездатність приступити до іншої роботи, доки «не перегорить негатив» мають переважно касири (45\% осіб), а в інших досліджуваних переважають середні показники тривалості емоцій.

Негативний вплив емоцій на ефективність діяльності і спілкування виявлено у $20 \%$ керівників відділень банків, у $35 \%$ фінансових консультантів і $55 \%$ касирів. Середній рівень такого впливу характерний для $45 \%$ керівників і консультантів. Здатність до регулювання впливу емоцій на професійну діяльність і спілкування характерна для 35 \% керівники відділень. Відповідно до узагальненого показника негативної емоційності - високий рівень проявляється більшою мірою серед касирів (50\%), у керівників і фінансових консу- льтантів - середні показники (45 \% і 40 \% відповідно). Оптимальний, низький, показник - у третини керівників (30 \%), 25 \% консультантів і $15 \%$ касирів. Отже, оптимальні показники емоційності більш характерні для керівників відділень банків і фінансових консультантів, а касирам - негативна емоційність.

Аналіз рівнів емоційної стабільності показує, що в переважної більшості досліджуваних - 43,3 \% осіб - середній рівень (див. Табл. 1).

Табличя 1.

\section{Показники рівнів емоційної стабільності працівників банків}

\begin{tabular}{|l|c|c|c|}
\hline \multicolumn{1}{|c|}{$\begin{array}{l}\text { Досліджу- } \\
\text { вані }\end{array}$} & \multicolumn{3}{|c|}{ Рівень емоційної стабільності, \% } \\
\cline { 2 - 4 } & Високий & Середній & Низький \\
\hline $\begin{array}{l}\text { Керівники } \\
\text { відділень }\end{array}$ & 50,0 & 45,0 & 5,0 \\
\hline $\begin{array}{l}\text { Фінансові } \\
\text { консульта- } \\
\text { нти }\end{array}$ & 20,0 & 55,0 & 25,0 \\
\hline Касири & 10,0 & 30,0 & 60,0 \\
\hline Всього & 43,3 & 26,7 & 30,0 \\
\hline
\end{tabular}

Їх можна схарактеризувати як помірно дратівливих, здатних до контролю емоційних станів.

Для третини досліджуваних (30 \% осіб) властивий низький рівень емоційної стабільності, що характеризує їх як нездатних до особистісного контролю емоційних станів, і таких, що мають високий прояв дратівливості.

Оптимальні показники емоційної стабі- 
льності виявлено тільки у 26,7 \% осіб, що свідчить про низький рівень дратівливості, високий ступінь особистісного контролю емоційних станів, здатність регулювати власну поведінку залежно від емоційної насиченості ситуації, вміння обмежувати вплив негативних ся із низьким рівнем особистісного контролю емоційних станів і високим проявом дратівливості, однозначно проявляється серед касирів (у $60 \%$ осіб) і у $25 \%$ фінансових консультантів. У 5 \% керівників відділень банків - низька емоційна стабільність.

Таблиия 2.

Показники рівня позитивної емоційності досліджуваних

за методикою В. Русалова (у \%)

\begin{tabular}{|c|c|c|c|c|}
\hline \multirow{2}{*}{\multicolumn{2}{|c|}{ Досліджувані }} & \multicolumn{3}{|c|}{$\begin{array}{c}\text { Рівень } \\
\text { позитивної емоційності, \% }\end{array}$} \\
\hline & & Високий & Середній & Низький \\
\hline \multirow{3}{*}{$\begin{array}{l}\text { Керівники } \\
\text { відділень }\end{array}$} & комунікативна & 40 & 60 & 0 \\
\hline & інтелектуальна & 45 & 50 & 5 \\
\hline & психомоторна & 40 & 50 & 10 \\
\hline \multicolumn{2}{|c|}{ Загальна позитивна емоційність } & 40 & 50 & 10 \\
\hline \multirow{3}{*}{$\begin{array}{l}\text { Фінансові } \\
\text { консульта- } \\
\text { нти }\end{array}$} & комунікативна & 40 & 30 & 30 \\
\hline & інтелектуальна & 35 & 55 & 10 \\
\hline & психомоторна & 35 & 40 & 25 \\
\hline \multicolumn{2}{|c|}{ Загальна позитивна емоційність } & 35 & 40 & 25 \\
\hline \multirow{3}{*}{ Касири } & комунікативна & 30 & 40 & 30 \\
\hline & інтелектуальна & 10 & 35 & 55 \\
\hline & психомоторна & 25 & 40 & 35 \\
\hline \multicolumn{2}{|c|}{ Загальна позитивна емоційність } & 25 & 40 & 35 \\
\hline
\end{tabular}

емоцій на продуктивність діяльності.

Висока емоційна стабільність найбільш характерна для керівників (50\% осіб), у фінансових консультантів і касирів (20\% і $10 \%$ відповідно). При цьому негативний іiї полюс низька емоційна стабільність, що сполучаєть-
За результатами дослідження у 43,3 \% досліджуваних комунікативна емоційність відповідає середньому рівню, а в 36,7 \% - високому (див. Табл. 2). Це вказує на їх здатність адекватно застосовувати різні прийоми для регулювання емоційних реакцій і гармонізації вза- 
ємин із клієнтами при наданні необхідної інформаційної допомоги, вміння попереджати i вирішувати міжособистісні конфлікти, отримувати позитивні емоції у процесі спілкування з іншими.

Високі показники інтелектуальної емоційності були у 30 \% осіб. Це свідчить про їх здатність отримувати позитивні емоції з процесу пізнання чогось нового, набувати та оновлювати власні знання і вміння, готовність до інноваційної діяльності. Середній рівень інтелектуальної емоційності був у 46,7 \% осіб.

Психомоторна емоційність на високому рівні була у 33,3\% осіб. Це свідчить про їх здатність отримувати позитивні емоції від будь-якої рухової активності, вправ і діяльності.

У 43,3\% осіб - середній прояв психомоторної емоційності. Низькі показники вищевказаних видів емоційності властиві для 20 $-23,4$ \% осіб, які відрізняються нездатністю до отримання позитивних емоцій від різних видів діяльності, недостатністю усвідомлення власних емоційних реакцій, розпізнання емоційних станів (як своїх, так й інших).

За загальним показником позитивної емоційності у третини досліджуваних (33,3 \%) високі значення. Вони здатні отримувати позитивні емоції з будь-якої діяльності, вміють контролювати власні емоційні реакції, розпізнавати емоційні стани інших людей та надати їм підтримку і допомогу. У 43,3 \% осіб - середній рівень емоційності (здатні до усвідомлення влас- них емоцій, контролю над емоційним станом, рефлексії переживань, можуть надати підтримку іншим). У решти - 23,3 \% осіб - низький рівень емоційності. Вони неготові до регуляції власних емоційних реакцій, схильні до неадекватних і деструктивних способів поведінки при взаємодії з клієнтами, колегами, керівництвом тощо.

Щодо комунікативної емоційності керівників, то вона була високою або середньою (40\% і 60 \% відповідно). Показники інтелектуальної та психомоторної емоційності в $40 \%$ керівників також були високими, а середні показники - у $50 \%$ осіб.

У $40 \%$ фінансових консультантів рівень комунікативної емоційності - високий. При цьому рівень інтелектуальної емоційності у 55 \% консультантів - середній, а у $35 \%$ високий. У більшості консультантів середній і високий рівні психомоторної емоційності (40\% і $35 \%$ ). Відповідно до виявленої величини загальної позитивної емоційності - у $40 \%$ фінансових консультантів - середній рівень, а у $35 \%$ - високий.

У касирів виявлено середній рівень комунікативної і психомоторної емоційності (40\% осіб) та у $55 \%$ осіб - низький рівень інтелектуальної емоційності. Високий рівень емоційності виявлено тільки у $25 \%$-30 \% касирів. За узагальненим показником більшість касирів мають середній і низький рівні емоційності (40 \% і 35 \%). Отже, високі, оптимальні показники емоційності як здатності до 
сприйняття, усвідомлення, рефлексії емоцій, регуляції емоційних станів, властиві для $40 \%$ керівників, $35 \%$ фінансових консультантів i $25 \%$ касирів. Низькі характеристики емоційності, що вказують на емоційну незрілість людини, виявлено у 35 \% касирів, у керівників і консультантів такі показники відповідно $10 \%$ та $25 \%$.

За узагальненим показником емоційної самосвідомості встановлено, що високим рівнем володіють 33,3 \% досліджуваних. Це вказує на їх здатність до усвідомлення власних емоцій, до сприйняття стану іншої людини, вміння відображувати емоції у власній експресивній мові та міміці, а також вміння нести відповідальність за вираження емоцій, передусім, в емоційно напружених ситуаціях. Такі досліджувані емпатійні, здатні співчувати іншим, ввійти в їх становище, співпереживати разом 3 ними, надати емоційну підтримку i допомогу за потреби. Вони вміють управляти власними емоціями, застосовувати прийоми саморегуляції психоемоційного стану, адекватно використовують навички регулювання при вирішенні стресових і проблемних ситуацій. Вказані особливості поведінки і властивості опитуваних характеризують емоційно зрілу особистість, отже, серед опитаних працівників банків тільки третина відрізняється показниками емоційної зрілості. Середній рівень емоційної самосвідомості виявлено у 43,3 \% осіб. У 23,3 \% банківських працівників - низькі показники емоційної самосвідомості.
Отже, високий рівень емоційної самосвідомості був у половини (50\%) керівників відділень банків, у третини (35\% осіб) консультантів і незначний прояв у касирів (15\% осіб). Щодо низького рівня емоційної самосвідомості, який вказує на емоційну незрілість людини, то його виявлено у 45 \% касирів, у $10 \%$ керівників відділень банків і $15 \%$ фінансових консультантів. Певні закономірності прояву їх емоційної зрілості наведено у Табл. 3.

Висновки. На основі отриманих даних було встановлено характерні психологічні особливості емоційно зрілих і незрілих працівників банків. Для емоційно зрілих працівників характерні: а) висока і середня емоційна стабільність, що виражається у показниках низької дратівливості та високого особистісного контролю над емоціями та емоційними станами; б) низькі, оптимальні характеристики негативної емоційності, i, відповідно, низька емоційна збудливість, імпульсивність, негативний вплив емоцій на ефективність діяльності і спілкування; в) високий рівень позитивної емоційності, що виявляється у здатності до отримання, розпізнання і вираження емоцій в будьякому виді діяльності (комунікативна, інтелектуальна, психомоторна); г) високий рівень емоційної самосвідомості, що виявляється у здатності до диференціації і вираження емоцій, прийняття відповідальності за емоції, управління емоціями, високі прояви емпатії.

Показниками емоційної незрілості є: а) 


\section{Характеристики емоційної зрілості у працівників банків}

\begin{tabular}{|c|c|c|c|c|c|c|c|c|c|c|}
\hline \multirow[t]{8}{*}{ Рівень } & \multirow[t]{8}{*}{ Всього } & \multicolumn{3}{|c|}{ Емоційно зрілі } & \multicolumn{3}{|c|}{$\begin{array}{c}\text { Середня } \\
\text { емоційна зрілість }\end{array}$} & \multicolumn{3}{|c|}{$\begin{array}{l}\text { Емоційно незрі- } \\
\text { лі }\end{array}$} \\
\hline & & $\mathrm{B}$ & $\mathrm{C}$ & $\mathrm{H}$ & $\mathrm{B}$ & $\mathrm{C}$ & из & $\mathrm{B}$ & $\mathrm{C}$ & $\mathrm{H}$ \\
\hline & & и & $\mathrm{e}$ & и & и & ep & b & и & e & и \\
\hline & & $\mathrm{c}$ & $\mathrm{p}$ & 3 & $\mathrm{c}$ & ед & $\kappa$ & $\mathrm{c}$ & $\mathrm{p}$ & 3 \\
\hline & & o & $\mathrm{e}$ & b & o & ні & и & o & $\mathrm{e}$ & b \\
\hline & & к & д & к & к & & & к & д & к \\
\hline & & и & $\mathrm{H}$ & и & и & & & и & $\mathrm{H}$ & и \\
\hline & & & $\mathrm{i}$ & & & & & й & $\mathrm{i}$ & \\
\hline \multicolumn{11}{|c|}{ Рівні емоційної стабільності } \\
\hline Висока емоційна стабільність & 16 & 10 & & & 6 & & & - & & \\
\hline Середні значення & 26 & & 10 & & & 14 & & & 2 & \\
\hline Низька емоційна стабільність & 18 & & & - & & & 6 & & & 12 \\
\hline \multicolumn{11}{|l|}{ Загальний показник негативної емоційності } \\
\hline Високий рівень негативної емоційності & 22 & 2 & & & 8 & & & 12 & & \\
\hline Середній рівень & 24 & & 6 & & & 16 & & & 2 & \\
\hline Низький рівень, оптимальний показник & 14 & & & 12 & & & 2 & & & - \\
\hline \multicolumn{11}{|c|}{ Показники загальної позитивної емоційності } \\
\hline Високий рівень & 20 & 16 & & & 4 & & & - & & \\
\hline Середній рівень & 26 & & 4 & & & 22 & & & - & \\
\hline Низький рівень позитивної емоційності & 14 & & & - & & & & & & 14 \\
\hline \multicolumn{11}{|c|}{ Загальний показник емоційної самосвідомості } \\
\hline Високий рівень & 20 & 16 & & & 4 & & & - & & \\
\hline Середній рівень & 26 & & 4 & & & 22 & & & - & \\
\hline Низький рівень & 14 & & & - & & & - & & & 14 \\
\hline
\end{tabular}

низька емоційна стабільність; б) високий рівень негативної емоційності; в) низький рівень позитивної емоційності; г) низький рівень сформованості емоційної самосвідомості.

Емоційна незрілість працівників зумовлює внутрішні конфлікти, відсутність контакту зі своїми почуттями і бажаннями, неадекватне самовираження, відсутність відчуття психологічного благополуччя, дезадаптацію у зовнішньому світі, дисгармонійні стосунки 3 іншими, низьку якість виконуваної професійної діяльності, низький рівень комунікативних якостей, а результатом є неуспішність виконуваної діяльності, погіршення якості обслуговування клієнтів банку. Тому доцільно прове- сти роботу 3 даною категорією працівників банку, спрямовану на розвиток у них емоційного інтелекту, формування здатності до управління емоціями і регуляції поведінки, що оптимізує формування у них емоційної зрілосTi.

\section{Перспективи подальших розвідок}

вбачаються у поглибленні уявлень про механізми функціонування емоційно зрілої особистості, у побудові тренінгових програм, спрямованих на розвиток вмінь управляти своїми емоціями та емоціями інших людей. 


\section{Перелік використаних джерел:}

1.Антонова Н.О. Взаємозв'язок психологічної та професійної зрілості студентів психологічного факультету ВНЗ / Н. О. Антонова // Актуальні проблеми психології: зб-к наук. пр. - Том 8. Психологічна теорія і технологія навчання. - 2010. - Вип. 7. C. $6-20$.

2.Власова О. I. Психологія соціальних здібностей: структура, динаміка, чинники розвитку: монографія / О. I. Власова. - Київ: ВПЦ «Київський університет», 2005. $308 \mathrm{c}$.

3.Кандыба М.О. Психологические особенности эмоциональной зрелости личности / М.О. Кандыба // Наука и образование - новое измерение. Педагогика и психология. - 2014. - № 20. - Т. II (10). - С. 122125.

4.Кочарян О. С. Емоційна зрілість особистості: дослідження феномену / О.С. Кочарян, М.А. Півень // Науковий вісник Миколаївського державного університету ім. В. Сухомлинського. Сер.: Психологічні науки. - 2012. - Вип. 9. - С. 140-144.

5. Півень M. A. Структурні особливості емоційної зрілості особистості : Автореф. дис. канд. психол. наук : 19.00.01 - загальна психологія, історія психології / М. А. Півень. - ХНУ ім. В. Н. Каразіна. - Харків, 2017. - 18 с.

6.Чудина E. A. Эмоциональная зрелость личности: определение понятия и выделение критериев / Е. А. Чудина // Личность и проблемы развития : сборник работ молодых учёных / отв. ред. Е. А. Чудина. Москва: Изд-во ИП РАН, 2003. - С. 112-116.

7.Singh $Y$. Manual for Emotional Maturity Scale / Y. Singh, M. Bhargava. - Agra : National Psychological corporation, 1990. $-153 \mathrm{p}$.

\section{References (Transsliteration):}

1. Antonova N. O. Vzajemozv'jazok psyhologichnoi' ta profesijnoi' zrilosti studentiv psyhologichnogo fakul'tetu
VNZ / N. O. Antonova // Aktual'ni problemy psyhologii': zb-k nauk. pr. - Tom 8. Psyhologichna teorija i tehnologija navchannja. - 2010. - Vyp. 7. - S. 6-20.

2. Vlasova O. I. Psyhologija social'nyh zdibnostej: struktura, dynamika, chynnyky rozvytku: monografija / O. I. Vlasova. - Kyi'v: VPC «Kyi'vs'kyj universytet», 2005. $308 \mathrm{~s}$.

3. Kandyba M. O. Psihologicheskie osobennosti jemocional'noj zrelosti lichnosti / M.O. Kandyba // Nauka i obrazovanie - novoe izmerenie. Pedagogika i psihologija. 2014. - № 20. - T. II (10). - S. 122-125.

4. Kocharjan $O . \quad S$. Emocijna zrilist' osobystosti: doslidzhennja fenomenu / O.S. Kocharjan, M.A. Piven' // Naukovyj visnyk Mykolai'vs'kogo derzhavnogo universytetu im. V. Suhomlyns'kogo. Ser.: Psyhologichni nauky. 2012. - Vyp. 9. - S. 140-144.

5. Piven' M. A. Strukturni osoblyvosti emocijnoi' zrilosti osobystosti : Avtoref. dys. kand. psyhol. nauk : 19.00.01zagal'na psyhologija, istorija psyhologii' / M. A. Piven'. HNU im. V. N. Karazina. - Harkiv, 2017. - 18 s.

6. Chudina E. A. Jemocional'naja zrelost' lichnosti: opredelenie ponjatija i vydelenie kriteriev / E. A. Chudina // Lichnost' i problemy razvitija : sbornik rabot molodyh uchjonyh / otv. red. E. A. Chudina. - Moskva: Izd-vo IP RAN, 2003. - S. 112-116.

7. Singh $Y$. Manual for Emotional Maturity Scale / Y. Singh, M. Bhargava. - Agra : National Psychological corporation, 1990. - $153 \mathrm{p}$. 


\section{Vashchenko Iryna}

Doctor of Psychological Science, Professor, Professor of the Department of General Psychology, Taras Shevchenko National University of Kyiv, Kyiv (Ukraine)

\section{Onufriieva Liana}

Ph.D. in Psychological Science, Assistant Professor, Professor of the Department of General and Applied Psychology, Head of the Department of General and Applied Psychology, Kamianets-Podilskyi National Ivan Ohiienko University, Kamianets-Podilskyi (Ukraine)

\section{ESSENTIAL CHARACTERISTICS AND STRUCTURAL COMPONENTS OF THE COMMERCIAL BANKS EMPLOYEE'S EMOTIONAL MATURITY}

\section{ABSTRACT}

The review and analysis of the problem on the emotional maturity of a personality are presented in the article. The notion of the emotional maturity in the works of prominent modern psychologists is substantiated. It is shown that the development of emotional maturity is important for socionomic professions specialists, including bank employees. The psychological features of the commercial banks employee's emotional maturity are proved to be as follows: emotionally mature workers have high and average emotional stability; low, optimal characteristics of negative emotionality; high level of positive emotionality; high level of emotional self-consciousness; emotionally immature workers have low emotional stability; high level of negative emotionality; low level of positive emotionality and the emotional self-consciousness formation. The criteria of the emotional maturity of a personality are shown to be: sensitivity, openness to emotional experience; awareness; adequacy of manifestation and ex- pression of feelings (correspondence to the external situation, internal state); psychological wellbeing (self-confidence, life satisfaction, lack of psychosomatic symptoms); mature ways of transforming emotions (sublimation, humor, creativity); arbitrariness (the ability to manage personal emotional experiences and personal behavior).

The indicators of emotional immaturity are established to be: a) low emotional stability; b) high level of negative emotionality; c) low level of positive emotionality; d) low level of emotional self-consciousness formation.

The emotional immaturity of employees is studied to lead to internal conflicts, the lack of contact with their feelings and desires, inadequate self-expression, the lack of psychological wellbeing, maladaptation in the outside world, disharmonious relationships with others, low quality of professional activities, low level of communicative qualities, and the result is the failure of the activities, deterioration of the quality of bank customer service. Therefore, it is advisable to work with this category of bank employees, aimed at developing their emotional intelligence, forming the ability to manage emotions and regulate behavior that optimizes the formation of their emotional maturity.

Key words: emotional maturity, employee of a commercial bank, emotional stability, emotional self-consciousness. 


\section{Ващенко Ирина Владимировна}

Доктор психологических наук, профессор, профессор кафедры общей психологии, Киевский начиональный університет имени Тараса Шевченко., г. Киев (Украина)

\section{Онуфриева Лиана Анатольевна}

Кандидат психологических наук, дочент, профессор кафедры, заведуюший кафедрой общей и практической психологии, Каменеи-Подольский национальный университет имени Ивана Огиенко, г. Каменеи-Подольский (Украина)

\section{СУЩНОСТНЫЕ ХАРАКТЕРИСТИКИ И СТРУКТУРНЫЕ КОМПОНЕНТЫ ЭМОЦИОНАЛЬНОЙ ЗРЕЛОСТИ РАБОТНИКОВ КОММЕРЧЕСКИХ БАНКОВ}

Аннотация. В статье представлен обзор и анализ проблемы эмоциональной зрелости личности. Обосновано понимание эмоциональной зрелости в трудах выдающихся психологов современности. Показано, что развитие эмоциональной зрелости, очень важны, для работников социономических профессий, к которым относятся и банковские работники. Доказано, что психологические особенности эмоциональной зрелости работников коммерческих банков следующие: в эмоционально зрелых - высокая и средняя эмоциональная стабильность; низкие, оптимальные характеристики негативной эмоциональности; высокий уровень положительной эмоциональности; высокий уровень эмоциональной самосознания; в эмоционально незрелых - низкая эмоциональная стабильность; высокий уровень негативной эмоциональности; низкий уровень положительной эмоциональности и сформированности эмоциональной самосознания. Определено, что критериями эмоциональной зрелости личности являются: чувствительность, открытость эмоциональном опыта; осознанность; адекватность проявления и выражения чувств (соответствие внешней ситуации, внутреннему состоянию) психологическое благополучие (уверенность в себе, удовлетворенность жизнью, отсутствие психосоматических симптомов); зрелые способы преобразования эмоций (сублимация, юмор, творчество) произвольность (умение управлять собственными эмоциональными переживаниями и своим поведением).

Ключевые слова: эмоциональная зрелость, работник коммерческого банка, эмоциональная стабильность, эмоциональное самосознание.

Дата отримання статті: 21.04 .2018 Дата рекомендації до друку: 17.05.2018 Дата оприлюднення: 24.05.2018 